\title{
Living Offline
}

\section{A Qualitative Study of Internet Non-Use in Great Britain and Sweden}

\author{
Bianca Christin Reisdorf \\ University of Oxford, Oxford Internet Institute \\ United Kingdom \\ bianca.reisdorf@oii.ox.ac.uk \\ Ann-Sofie Axelsson \\ Chalmers University of Technology \\ Sweden \\ ann-sofie.axelsson@chalmers.se \\ Hanna Maurin Söderholm \\ University College of Borås \\ Sweden \\ hanna.maurin@hb.se
}

\section{Abstract}

This study explores and compares attitudes and feelings of middle-aged British and Swedish Internet non-users as well as their reasons for being offline. The rich qualitative data are conceptualized and presented according to various reasons for non-use, positive and negative feelings regarding non-use, and the positive as well as negative influence of and dependence on social networks. The comparison shows both unique and common perceptions of the British and Swedish respondents, some of which can be attributed to social, economic, or socio-economic factors. However, it also displays vast differences between middle-aged nonusers in both countries. The analysis paints a complex picture of decisions for and against the use of the Internet and the need for more research to understand these highly complex phenomena, which cannot simply be attributed to socio-economic backgrounds as has been done in most previous research. The analysis shows that more complex reasons, such as lack of interest or discomfort with technologies, as well as the somewhat surprising finding that social networks can prevent non-users from learning how to use the Internet, as it is more convenient to stay a proxy-user, should be considered in future research and policies regarding digital inequalities. 


\section{Keywords}

Internet non-use; digital inequalities; cross-country comparison; qualitative research

\section{Introduction}

With increasing proportions of Internet users in developed countries, the focus of digital inequality research has shifted towards examining different types of Internet use and users. Internet non-use has accordingly become an under-researched topic over the past decade. A number of recent studies focus on distinguishing different types of users, and established that low use or staggered use of the Internet can pose a disadvantage for these low users in various areas of their lives, as many of them have already socio-economically disadvantaged backgrounds, such as low income or low educational qualifications (e.g. Helsper, 2011; White \& Selwyn, 2011; Zillien \& Hargittai, 2009). If we regard low use as potentially problematic and disadvantageous, then within that world-view complete non-use might be an even bigger problem. Hence, non-users, their characteristics, experiences with non-use in everyday life, attitudes, and reasons for non-use should be examined carefully. This paper will examine Internet non-use of Britons and Swedes aged 25 to 55 years.

With regards to digital inequalities and Internet use and non-use we find a large proportion of studies on young people (e.g. Hargittai \& Hinnant, 2008; Livingstone \& Helsper, 2007) and the elderly (e.g. Kiel, 2005; Milligan \& Passey, 2011). Middle-aged populations have thus far not specifically been looked at. However, this age group is particularly interesting, as they are likely to be part of the work force for at least 10 more years. Many jobs require use of computers and the Internet nowadays. Moreover, this group is more likely than any other age group to have children living in the household who often use computers and the Internet for 
schoolwork and in their leisure time. Internet non-use might thus be especially problematic for this age group.

A cross-country comparison of two highly developed and technologized countries such as Great Britain and Sweden is fruitful as they share similarities in terms of economic development, but also differ with regards to policies regarding the Internet, cultural perceptions of technologies, and proportions of non-users. While we find 12 per cent non-users in the middle-aged British population (2011 data from Oxford Internet Surveys; Reisdorf, forthcoming), there were less than 2 per cent nonusers in the same group in Sweden (2011 data from World Internet Institute; Reisdorf, forthcoming).

Qualitative semi-guided interviews will give insight into experiences and attitudes as well as reasons for staying offline. The detailed data bring a new dimension to non-user research that has not been investigated a lot before. While a small amount of qualitative work has been done on British Internet non-users, a systematic literature search in spring 2012 showed that no qualitative research has been done on Swedish non-users. This paper will examine these factors for middleaged Internet non-users in Great Britain and Sweden on basis of a qualitative research design.

\section{Research Questions}

Over the last decade governments in Europe have recognized the link between socio-economic inequalities and digital disengagement reported in research. Accordingly, lack of economic resources and access is what policies focus on in their efforts to tackle digital inequalities. Most studies focus on physical access and neglect other issues such as lack of knowledge about technologies, attitudes towards technologies, or lack of skills or interest in the Internet (see also Eynon \& Helsper, 2011; Selwyn, 2003, 2004). To know how to motivate Internet non-users to become users, the first step needs to be a thorough understanding of why they do not use the Internet in the first place. In light of the mostly quantitatively research in the area, digital inequality studies only rarely focus on underlying reasons for Internet non-use. To be able to develop a theoretical and practical understanding of non-use, it is essential to take this first step. Our first research question addresses this problem: 


\section{What reasons do non-users give for staying offline?}

Closely related to underlying reasons and motivations for non-use are attitudes towards technologies, as well as perceptions and experiences of non-users. The conscious or unconscious decision to be a non-user can be fuelled by many reasons, such as economic constraints, discomfort with using technologies, not seeing any benefit or avoiding some degree of reliance on technologies. The widely assumed negativity of Internet non-use makes offliners seem 'left behind' and perceived as outsiders (Klecun, 2008, p. 267). Many policy makers aim for 100\% Internet penetration and usage (e.g. Race Online, 2012) without considering that not using the Internet might be the right choice for some. To understand whether Internet non-use actually is a problem in today's highly technologized societies of developed countries - and if yes, for whom - the analysis of attitudes, perceptions, and experiences of non-users themselves is key. Only then can useful and sensible policy agendas regarding e-Inclusion be designed. Accordingly, our second research question asks:

2. How do non-users themselves perceive technologies and their offline lives, and how do they 'get on' in a highly technologized world?

\section{Research Design}

To tackle these questions we conducted semi-structured interviews with 10 Internet non-users in Great Britain and Sweden respectively. The British interviews were mainly conducted in and around Birmingham, which is after London the most populous British city. London displays an unusually high proportion of 83 per cent of households with Internet access (Office for National Statistics, 2010, p. 7) in contrast to 74 per cent averaged across Great Britain. On the other hand, the West Midlands and Birmingham are areas more similar to the British average with 73 per cent of all households having access to the Internet (Office for National Statistics, 2010, p. 7). The Swedish average is much higher. In 2011, 93 per cent of the Swedish population aged 16-74 had Internet access at home (Statistics Sweden, 2011, p. 11). The interviews with Swedish non-users were mainly conducted in and around the secondlargest city in Sweden: Gothenburg, and its surrounding regions. In total, 20 people in the age 25-55 were interviewed in the spring of 2012, 10 in Sweden and 10 in Great Britain. 
The interviewees were selected through purposive sampling (Miles \& Huberman, 1994, pp. 27 et seq.; Patton, 2002, p. 230). This approach was inspired by the concept of theoretical sampling by Glaser and Strauss (1967), which aims "[...] at that material that promises the greatest insights, viewed in the light of the material already used, and the knowledge drawn from it" (Flick, 2009, p. 118). The selection was informed by the research questions as well as previous results in this field. The interviewees were initially recruited via UK Online Centers IT beginner courses, Swedish adult learning centers, libraries, community centers, and later through snowball sampling and follow-up phone calls to UK survey respondents. Despite applying the same recruitment strategies in both countries, the samples differ in terms of variety of socio-economic background characteristics with the Swedish sample being more diverse than the British one. Tables 1 and 2 below describe the socioeconomic characteristics of participants in Britain and Sweden.

Table 1: Socio-economic characteristics of British interviewees

\begin{tabular}{|c|c|c|c|c|c|c|c|}
\hline No & $\begin{array}{l}\text { Name in } \\
\text { Study }\end{array}$ & Age & Gender & Nationality & $\begin{array}{l}\text { School } \\
\text { Qualifications }\end{array}$ & Occupation & $\begin{array}{l}\text { Living } \\
\text { Situation }\end{array}$ \\
\hline 1 & Paul & 53 & Male & English & None & $\begin{array}{l}\text { Machine } \\
\text { Operator }\end{array}$ & $\begin{array}{l}\text { With wife, } \\
\text { daughter (16) }\end{array}$ \\
\hline 2 & Lisa & 55 & Female & English & None & Unemployed & Alone \\
\hline 3 & Martin & 50 & Male & English & GCSES & Unemployed & Alone \\
\hline 4 & Tom & 54 & Male & English & $\begin{array}{l}\text { O-levels (now } \\
\text { GCSEs) }\end{array}$ & Unemployed & Alone \\
\hline 5 & Georgina & 53 & Female & English & GCSEs & Unemployed & Alone \\
\hline 6 & Rita & 52 & Female & English & $\begin{array}{l}\text { GCSEs, } \\
\text { NVQ2, NVQ3 }\end{array}$ & $\begin{array}{l}\text { Care } \\
\text { Assistant }\end{array}$ & $\begin{array}{l}\text { With husband, } \\
\text { daughters } \\
(21,25)\end{array}$ \\
\hline 7 & David & 49 & Male & English & None & $\begin{array}{l}\text { Self- } \\
\text { employed } \\
\text { all-rounder }\end{array}$ & Alone \\
\hline 8 & Barbara & 48 & Female & English & A-levels & Lorry driver & Alone \\
\hline 9 & Gail & 55 & Female & Welsh & $\begin{array}{l}\text { Bachelor's } \\
\text { degree }\end{array}$ & $\begin{array}{l}\text { Out of work } \\
\text { for health } \\
\text { reasons }\end{array}$ & With husband \\
\hline 10 & Sandra & 56 & Female & English & None & $\begin{array}{l}\text { Self- } \\
\text { employed }\end{array}$ & $\begin{array}{l}\text { With husband, } \\
\text { son, } \\
\text { daughter-in- } \\
\text { law }\end{array}$ \\
\hline
\end{tabular}


While most of the British participants were older (48-56), working in low skilled trades or were unemployed, the Swedish sample includes a wider age range (28-56), more nationalities and a larger variety of different occupational statuses.

Table 2: Socio-economic characteristics of Swedish interviewees

\begin{tabular}{|c|c|c|c|c|c|c|c|}
\hline No & $\begin{array}{l}\text { Name in } \\
\text { Study }\end{array}$ & Age & Gender & Nationality & $\begin{array}{l}\text { School } \\
\text { Qualifications }\end{array}$ & Occupation & $\begin{array}{l}\text { Living } \\
\text { Situation }\end{array}$ \\
\hline 1 & Karolina & 38 & Female & Swedish & $\begin{array}{l}\text { Grammar } \\
\text { school }\end{array}$ & Childcare & $\begin{array}{l}\text { With husband, } \\
\text { children }\end{array}$ \\
\hline 2 & Lina & 55 & Female & Lebanese & None & $\begin{array}{l}\text { Part-time } \\
\text { School }\end{array}$ & Alone \\
\hline 3 & Nasan & 32 & Female & Iraqi & None & $\begin{array}{l}\text { Part-time } \\
\text { School }\end{array}$ & $\begin{array}{l}\text { With husband, } \\
\text { sister, } \\
\text { daughter (7) }\end{array}$ \\
\hline 4 & Mai & 39 & Female & Vietnamese & None & $\begin{array}{l}\text { Part-time } \\
\text { School }\end{array}$ & $\begin{array}{l}\text { With husband, } \\
\text { children }(2,4)\end{array}$ \\
\hline 5 & Piotr & 56 & Male & Bosnian & $\begin{array}{l}\text { Compulsory } \\
\text { school }\end{array}$ & Unemployed & With children \\
\hline 6 & Annika & $\begin{array}{l}\text { Late } \\
20 \text { s }\end{array}$ & Female & Swedish & $\begin{array}{l}\text { Compulsory } \\
\text { school }\end{array}$ & $\begin{array}{l}\text { Handicraft } \\
\text { work }\end{array}$ & With mother \\
\hline 7 & Johan & 48 & Male & Swedish & $\begin{array}{l}\text { Grammar } \\
\text { school }\end{array}$ & $\begin{array}{l}\text { Contract } \\
\text { work }\end{array}$ & With wife \\
\hline 8 & Hanna & 34 & Female & Swedish & $\begin{array}{l}\text { Compulsory } \\
\text { school }\end{array}$ & Unemployed & $\begin{array}{l}\text { With husband, } \\
\text { children }(2,4)\end{array}$ \\
\hline 9 & Kerstin & 53 & Female & Swedish & University & Childcare & With husband \\
\hline 10 & Emil & 51 & Male & Swedish & $\begin{array}{l}\text { Compulsory } \\
\text { school }\end{array}$ & Actor & $\begin{array}{l}\text { With wife, } \\
\text { children (8, } \\
\text { 13) }\end{array}$ \\
\hline
\end{tabular}

We used a semi-structured interview-guide with open-ended questions in order to explore respondents' perceptions of Internet non-use in the light of "the personal worldview of the interviewee [...] in detail" (Gaskell, 2000, p. 46). The interviewguide was informed by questions brought up by previous quantitative analyses of this specific group (Reisdorf, 2011). It focused on perceptions of different ICTs $^{1}$ and devices, such as TV and mobile-phones, but mainly on computers and the Internet; and on probes, conceptualized as every-day situations such as banking, shopping or buying train-tickets, where the use of Internet-based technology might be necessary.

\footnotetext{
${ }^{1}$ We understand information and communication technologies (ICTs) as technologies that enable digital information gathering or communication with others. These include all Internet-based technologies and mobile technologies. As such, Internet use represents one of a number of ICT uses.
} 
To secure comparability and prepare for a straightforward analysis approach, we used similar questions and probes for both Great Britain and Swedish respondents.

The interviews were conducted face-to-face or by phone, and took place at a time and location selected by the interviewee, or at the location for recruitment, i.e. a library. The Swedish interviews were conducted in Swedish to keep the interviewees comfortable and avoid issues of ambiguity and miscommunication (Marshall \& While, 1994). All the interviews were digitally recorded, and transcribed. The Swedish data were transcribed in Swedish, then translated and analyzed in English.

Data analysis took place in several steps and was conducted by two researchers. As stated by Gaskell, the process of analyzing qualitative interviews includes several modes of analysis, from reading and re-reading to thematic coding and categorization (ib., pp. 53 et seq.). We analyzed the interviews starting with broad descriptions of the interviews and working towards a more detailed process of coding the interviews and categorization of important topics within the data. This process worked in "analytic circles" (Creswell, 1998, pp. 142 et seq.), which included the repetition of certain analytical methods such as categorization, comparison and contrasting of occurring themes within the data.

\section{Results}

Recruitment of interviewees in both countries proved to be difficult, with many non-users not being willing to participate and others agreeing initially and then refusing to participate later. Social desirability of using the Internet as promoted through the media and policies was already apparent in the recruitment of interviewees. One of the British interviewees mentioned that her husband was not using computers and the Internet, but said that he would not want to participate in the study as he struggled to admit to his non-use:

Interviewer: Do you think you could take a little information sheet and ask him, if he would be happy to talk to me?

Rita: He probably won't because he won't admit that he can't do computers. He's a man, you know.

One Swedish non-user refused to talk to us and others were reluctant, because they were worried that we were trying to sell them an Internet connection or 'make' 
them go online. Others, especially in Britain, were worried they would be judged for not using the Internet and needed reassurance before agreeing to participate.

Moreover, the social desirability was an underlying notion in most of the attitudes and feelings that the interviewees mentioned. During the interviews it seemed that the majority of the respondents felt like they 'should' be using the Internet, that they were expected to use it.

Interviewer: When you think about everyone around you using the Internet, how do you feel about that?

Gail: I do feel a little bit out of it, actually. Because I know it's something I should be doing more. [...]

Interviewer: And when you say you think you should, why do you think so?

Gail: Well, because I'm missing out on ... I haven't kept up with the times. It's an essential part of live these days, isn't it?!

The following sections will present different reasons for not using the Internet including: no interest or need; technology discomfort; complexity and complication; physical impairment; refusal; and, social network. This is followed by an analysis of different feelings in relation to non-use, including: being happy with it; feeling different; and, regret. Finally, results pertaining social networks, influence and dependence will be presented. Overall, we found unique and common perceptions and variations both within and between British and Swedish non-users and results will be underpinned with quotes from both groups of interviewees.

\subsection{Reasons for Non-Use}

As Internet use is widely spread and omnipresent in media and everyday life, not doing something that the majority of a population does, such as not driving a car (Wyatt 2003), is likely have more behind it than 'no interest'. The reasons for non-use deriving from the interview study are manifold and intertwined.

\section{No interest and no need}

Martin and David were both professional footballers when they were younger. They did not need to use the Internet or computers for their occupation. Accordingly, neither of them concerned themselves with these technologies until recently. Both of them say they were simply not interested in it: 
Martin: I was only interested in football [...], and I went on to play football for Coventry, Man United, Man City, Hong Kong. [...] I wasn't interested; I was just wanting to be a footballer.

David reported similar reasons and added that he did not need technologies for his later work or in his spare time, as he did mainly manual labour after his career as a sportsman ended. As his main hobby was still sports after the end of his professional sports career, he found information on what he was interested in in offline settings, such as books, magazines, and TV. Gail, who was working as a music teacher before a major operation that prevents her from leaving the house, said she did not need the Internet for her job. Another similar case was Paul who worked as a machine operator in a composting firm at the time of the interview.

In the Swedish sample Johan, Emil, and Kerstin stood out as having a clear disinterest in the Internet. Johan and Emil were self-employed and successful, but in quite different fields: Johan within contract work, handling and renting big machines within the building industry, and Emil as a freelancing actor. Kerstin worked within childcare. All three strongly expressed that they had no interest in the Internet:

Emil: I am completely uninterested in it. But I understand, on the other hand, that to many other people it is a source of happiness and joy but I have never had any need for using it.

Similar to Martin and David these Swedish non-users were interested in things that did not require any Internet use.

Kerstin: I have always been uninterested, I mean, to sit around, staring at the computer like some people do at work. That I find extremely boring. And also boring to do this at home - I rather go out, take a walk in the woods, do something in the garden, or drive off and do something, like take a daytrip. In fact, I rather do anything else. As it is, the computer comes last.

Looking deeper into these cases, however, it also became obvious that a number of those who said they did not need the Internet or were not interested in it were additionally lacking essential skills to do so and did not know what kinds of things people might use the Internet for. Paul, for example, also reported problems with the technology and problems with typing:

Paul: I'm just there looking for, where is $d$ \{laughs\}, you know, one finger here and then two and it's not worth it. It's 2 seconds and they've done it, they found it, they got what I want and that's it, and so I just sit there and read it through and say 'right, I finished' and they just come and knock it off.

These issues were reported by a number of interviewees, often regardless of their educational background. Many of them were also worried of breaking the 
computer, 'messing up', or 'getting it all wrong'. One of the interviewees was especially worried about this in light of others using the same computer:

Karolina: The anxiety is always there, that something will go wrong so that you destroy someone else's things on the computer.

\section{Discomfort with technologies}

This points to a second closely related reason for non-use. Interviewees in both countries mentioned the notion of discomfort in using technologies such as computers and the Internet. While many British non-users said that this was because these technologies were for a different generation, this was not mentioned at all by the Swedish sample. Several Swedish interviewees noted that young people and children use computers and mobile phones a lot, but more as a fact than saying that this is not for them, due to age.

A number of British and Swedish interviewees mentioned that they found specific aspects of Internet use scary, such as criminals being able to steal credit card details, worries about privacy, or the molesting of children via the Internet.

Interviewer: And is there any technology that you don't like to use?

Georgina: Yeah, I wouldn't like to go on the sites that man went on [conspiracy theories] I gotta admit. I think that would be quite SCARY. I think there's too much ... privately there's- people put very private things on the computer, which I think is a bit too- it's very scary.

Hanna had worries concerning addiction and that children grow up spending too much time online. This is a worry that she shares with Lina who also worries about 'dangerous' things that can be found by children on the Internet.

Lina: I think that I can't leave him [grandchild] alone at the computer all that time. I know that they are very good at finding other pages that are not good and look at that.

Rita was learning to use computers and the Internet at the time of the interview. She described her extremely negative feelings towards the Internet that she had until recently:

Rita: Hated computers, thought they were a waste of time, didn't wanna know them, thought they were taking over the world. But my two daughters, they're brought up with it-one's 25 , one's 21 , they both use computers and easy peasy for 'em. So, we've got one in the house, and l've just been sort of determined to try to come to grips with it, and not be scared of it - it's only a machine. 
Like many other British respondents she related to the Internet as being something that her generation had not grown up with. She explained that her age group was not as technology-prone as young people and that it was harder for them to accept them and learn how to use them. However, she admitted that she did not really understand what they were about, or why she was scared of them before she learned how to use them.

\section{Complexity and complication}

Difficulties in using technologies and discomfort with them are often related to the general feeling that using computers and the Internet was very complicated. All those interviewees who had only tried using the Internet a few times or who had just started learning how to use it reported feelings of frustration. It started with 'simple' things, such as the design of the keyboard, which was generally perceived as being complicated. David started using the Internet on his smartphone recently and mentioned struggling with computers:

Interviewer: So, when you think about computers instead of your phone how do you feel about all the keys, the keyboard, the mouse and stuff like that?

David: Well, yes, I mean, I must admit, sometimes I can get distracted with the mouse ... with the laptop with the screen. It can be sometimes too much for me. So, that was a problem at first. [...] That's why l've been doing most of the things on my own phone, on my own time.

Martin explained that apart from the basic technical problems with computers, there were a lot of things he would have to consider, if he decided to go online:

Martin: Especially when I was lookin' at the viruses and stuff, I found that difficult. And I thought, oh, even if you do get a computer you've gotta get all these viruses and everything to stop people latchin' on to your stuff.

This is only one of many examples where non-users got confused with terminology. Most of them were generally not sure of how the Internet 'works'. This is exemplary of how complex the technology and all the components that are needed for it to function properly are. For non-users it might be even more complicated to become users today than five or ten years ago. On the other hand, devices such as smartphones and tablets might overcome some of these technological hurdles as the quote from David shows. 
Another example is Piotr from Sweden, who said he never used the Internet himself, but got onto his smartphone during the interview and showed us the weather forecast for the region without realizing that his phone was connecting to the Internet to do so.

The majority of the Swedish sample expressed a general problem with handling ICTs other than the Internet; for example that they find texting on the mobile phone complicated, whereas a few others in the same sample do not text due to illiteracy.

Interviewer: Do you have a mobile phone?

Lina: Yes.

Interviewer: Do you use it?

Lina: Only for calling, I can't write with... sms or messages.

Interviewer: Do you send pictures?

Lina: No, No, can't use, it is hard for me.

\section{Physical impairments}

One of the British interviewees had vision impairment and was thus struggling to use ICTs of any type, which included the Internet. While she acknowledged that there were possibilities for her to use computers and the Internet, she found them too complicated. Her husband and family were using the Internet for her on a regular basis. Sandra felt that in this era of technologies, she would be stuck without the help of her husband.

Sandra: I mean if I didn't have my husband, I wouldn't be in this job. Because although I do my fair share of work, he's the one that does all the technical side of it with the computer. So without him, I would be stuck.

She described how the Royal National Institute of Blind offers computer courses for visually impaired people, but that she would also have to buy a completely new computer set, which is expensive and hard to set up. For her, having her husband use the Internet instead of her was a much better solution. However, Sandra also mentioned that it was frustrating for her to not be able to use these technologies herself.

Sandra: I do feel that I miss out. And what I also find is that I have friends and relatives that just want to communicate on the Internet, send emails, facebook. So that's all sort of closed to me really. 


\section{Refusal}

Only few interviewees named conscious refusal as their main reason for not using the Internet. Barbara stopped using the Internet and all other 'modern' technologies four years ago. After her divorce from her previous husband, she made a conscious decision to ban all things from her life that used to annoy her within the marriage. Technologies, such as TV, stereo, a landline, computers, and the Internet were not part of her current lifestyle.

Barbara: Everything that came with the marriage I've left behind and I have basically made a conscious decision not to reintroduce the technological things that used to annoy me until I'm personally ready for them.

As a lorry driver, she did not need any of these technologies for her work, and she did not feel like she was experiencing any major disadvantages from it that would make her become an Internet user again.

Barbara: I did my insurance online and searching for information online. [...] But now I go to the local insurance shop that's got a High Street's branch that I can walk in and speak to a real person rather than do it online. [...] I know I pay a bit extra. Doing things on the Internet is often cheaper nowadays, but l'm still rebuilding my life.

The only ICT present in her life was her mobile phone, with which she kept in touch with her adult sons who used the Internet for her every now and then. For her the negative association of the Internet and similar technologies with her previous life was a decisive reason to live without them until she felt ready to use them again.

Emil has also actively chosen to stay away from computers. A lack of interest in ICTs in general, along with political and ideological reasons has gradually developed into a conscious decision to resist computers as long as he can:

Emil: This has become a project of mine [to stay offline], this which wasn't a thought from the start but merely disinterest. Since I now realize that I belong to a rather small and exclusive group, if not only from a research perspective, it would be fun in the future with a 80, 90 year old who hasn't used computers.

These examples show that there are cases of non-use that have nothing or only very little to do with socio-economic background or lack of access and skills. It shows the importance of individual and psychological factors for the use of technologies. Both Barbara and Emil had the financial means to be online, but made a conscious decision to stay offline. In their current lifestyle, they did not see the need for Internet 
or computer use. However, Emil admits that he is in a privileged position because he has people working for him, doing banking, travel arrangements and such.

\subsection{Feelings about Non-Use}

Reasons for non-use and potential future use are related to the feelings of nonusers about being offline and potential (future) use or their progress with learning how to use computers. The different cases described below show that some non-users were content with being offline while others felt different from their peers or even 'stupid'.

\section{I'm happy with it}

As one of very few British respondents Paul said that he was happy with his own non-use and the proxy use through his wife and daughter:

Paul: I'm quite happy with that. I don't have to use the Internet in the work place. And I'm quite happy with that.

His feelings about his non-use were positive, because he had no need to use computers or the Internet in any part of his life. He did not need them to be more successful in his work and his family used the Internet for him, when he saw a need for it. Although their main reasons for non-use differ, Barbara and Paul were similar in terms of their feelings about their non-use. Barbara too did not see any need for computer or Internet use in her current life, as neither would improve her work or her private life. Similar to Paul, if Barbara saw the need to get information from the Internet, she would ask one of her sons to look it up for her. Neither of them mentioned feelings of being different or pressured by others to use the Internet.

In Sweden several interviewees reported being happy with their situation as they had family, friends, or hired staff (e.g. accountants) doing things online for them.

Piotr: It's good and I say: "I can't do anything, can you help me with this... viruses and such" and they [children] help me fix it.

Freelance actor Emil and contract worker Johan both had professional help for Internet related issues so that they did not have to deal with them themselves.

Emil: It's wonderful! I buy these services and for me it's perfect - I wish everyone could lead a life like this, but I understand, of course, that not everybody can afford it or live a life like that. 


\section{Being different}

A number of non-users in both countries mentioned a feeling of being different as well as a certain degree of pressure from their surroundings to use technologies, such as the Internet.

Lisa: I mean they [sisters] use the Internet all the - they're using it in their work business, and they're great. I'm the only one really, an' I'm the oldest. But they're very good at things, pick up things quick like that. An' I don't, I never have done that. I'm a bookworm, I read. I just read and read and read and read. So that's where I am. Well, we all can't be the same.

Lisa also reported a certain lack of understanding from her nieces and nephews, who all used technologies and helped her with her mobile phone on a regular basis. With them having grown up with these technologies, they did not understand why it was hard for her to deal with them:

Lisa: 'Cos even my li'l niece - she's 6 and she knows how to use the c- [...] there was a photo of my son that I wanted on my phone, and my nephew was staying with me at the time. He was ten at the time, he's eleven now. He says 'Oh, it's so easy, aunty Lisa', and he was doin' this, I said 'Oh, just do it'. 'Honestly, aunty Lisa, get with it, get with it'.

Many non-users reported being the only ones in their family or circle of friends who were offline. They mentioned feeling left out in conversations about things 'happening' on the Internet and were uncomfortable with not being able to join in.

Martin: I'm probably the last one. It's probably the reason why l've done it, 'cos they're talkin' about it and I'm like 'Right ...' you know.

In other cases this feeling went a step further to not only feeling left out, but also feeling stupid, such as mentioned by several interviewees in both countries:

Johan: And you notice in my kind of profession, it's a question of being available so that customers can reach you, usually via phone. But you notice that if you want to get information, people ask you whether you have email, and no, I haven't, and then it's almost like they think you are a bit stupid.

Hanna describes similar notions about this:

Hanna: If you tell people "I haven't got a computer" they think you are from the Middle Ages. Like, "WHAT, don't you have a computer?" 


\section{Regret}

For many of those non-users who did not explicitly express being happy with being offline the interviews carried a general notion of feeling behind, mirrored by a number of them saying that learning it now was a case of 'better late than never' or that not learning it before was a mistake:

Martin: It's just silly because I remember distinctly as I played in Hong Kong when I was about 24, so it's 25 years ago. There were no computers, were all just startin' an' I remember people talking the odd things. [...] But I mean I trained, and trained, an' l'd come for an hour [...] four days a week, the rest of me time was me own. Apart from match day, an' I think in all that time I coulda, and I know then I'd picked it up a lot quicker. But ... we all make mistakes, don't we.

In Sweden Karolina explicitly expressed regrets about not knowing how to use the Internet in relation to feeling like a burden to her husband and colleagues. She mentioned it would be easier for them, if she could do these things on her own:

Karolina: He [husband] gathers a lot of information as we're renovating our house, so a lot of information on how to do that and such is what he's getting.

Interviewer: And you think that is positive and useful things?

Karolina: Yes, it is. So maybe because of that you sometimes regret not being more interested in that, in fact. So you'd been able to do all that yourself.

\subsection{Social networks: influence and dependence}

In the context of adoption of technological innovations, social influence is often seen as one of the core concepts affecting technology adoption and use (Rogers, 1995). In our data we found subtle and complex nuances and differences in how the influence of social networks affected Internet non-use.

One difference between the Swedish and British data was the opposite effect that families' and friends' attitudes towards the Internet seemed to have on non-users. Some of the British data suggest that if respondents' friends and family were reluctant about using the Internet and their scope of use was narrow or sceptical, non-users often displayed similar opinions. A prime example for this was Paul, who was not using the Internet himself, but said that his wife was. However, she would not buy things online due to worries about credit cards and privacy:

Interviewer: And what do you think about holidays? You said earlier that your wife sometimes looks up holidays with you on the Internet. 
Paul: Yeah, we've looked on there at different holidays, yeah, it's good in that way, and we have actually booked holidays from there mainly in this country. We took it off the, the Internet and then talked to normal people direct, and done it that way, because that's one thing that my wife doesn't like doing, perhaps fair enough, there's a lot of spies. She won't give her card details out over travel on the Internet. Don't do any banking or anything like that. She just does it direct over the phone.

Similar to her, Paul reported sceptical feelings towards the Internet and did not want to try it. He preferred using telephone or face-to-face contacts in his private life.

Another unexpected difference between the Swedish and British respondents was related to how the presence of social networks, or lack thereof, were both reasons for non-use. All but one of our Swedish respondents were living together with other family members who used the Internet for them, compared to the British respondents where six of the ten interviewees lived alone. Some of these Swedish non-users stayed offline because it was more convenient for them to have other people use the Internet for them. While the support of their social networks meant they could use the Internet by proxy, it might also diminish incentives to learn how to use the Internet.

Interviewer: It seems like there are some things that your husband can do and that you might go to him with a question or task and then they [husband and daughter] do it for you? How do you feel about that?

Karolina: Well, how do I feel about that? It makes you a bit inflexible, because you always need to have someone around to help you and it's not very nice to them to ask them for help all the time, I don't do that but they are usually very helpful because he enjoys sitting [by the computer] so it works very well.

On the other hand, among our British respondents, several lived alone and mentioned being the only ones in their circle of friends who were not using the Internet. A number of those who did mention this were determined to start using it. Thus, the availability of warm experts (Bakardjeva, 2005; Selwyn et al. 2005) provides a support network that makes the move towards using technologies easier, which are perceived as complicated and hard to pick up. On the other hand, it might also make people rely on the "expert-help" so that they do not see the point in using the Internet themselves.

Although many of the respondents seemed content with people in their social network helping them, some of the Swedish interviewees - but none in the British sample - reported negative feelings about having to ask their family or colleagues to help them using the Internet. Hanna, who, currently on maternal leave, lived with her husband and two children in the Swedish countryside, felt that she ought to learn how to handle computers and the Internet. They had a laptop at home but no Internet 
connection due to economic reasons. Hanna also ascribed the feeling that she ought to learn how to use the Internet to implicit pressure from her family:

Hanna: So you always need to ask other people, if there is something you would like to look up. It feels a bit like 'Hello, couldn't you look that up yourself?' but I can't because then I need to travel to my sister with the children and that feels a bit unnecessary.

Interviewer: But sometimes you ask your sister for help to do that for you and then she does that for you and thinks it's okay?

Hanna: Yes, sure, or yes, she doesn't say no, she doesn't do that. But it feels like you are an adult person now and should be able to...

Karolina expressed a feeling that she was a burden to her colleagues in the kindergarten and to her husband and daughter, since they needed to support her in various situations related to Internet use. This constant need of help made Karolina feel left out.

Interviewer: You said that both at home and at work you are taking part in the work and helping out but you sit with or next to someone else using the computer, how do you feel about that at work?

Karolina: It can be a bit excluding, because I can't do those things on my own, whereas the other two [colleagues] can just go and do something I always need someone else's help.

\section{Discussion}

Middle-aged non-users in Great Britain and Sweden differ on a variety of characteristics - not only with regards to socio-economic background, but also in terms of reasons for being offline. We found a large range of reasons for non-use and feelings about this in both countries. All non-users had a number of reasons for being offline with some of these being more important than others. Two of the major reasons in both countries were lack of interest in the Internet, which relates to the lack of perceived added value to their current lifestyles, and social networks, which can have a positive influence on the wish to use the Internet, but also an effect of holding non-users back. Both will be discussed more below.

\section{Added Value and Social Networks}

A theory prominent in economics is the theory of added value. Applying it to information markets, Kuhlen (1996) differentiates a number of potential added values: 
organizational, strategic, innovative, macroeconomic, efficiency, effectiveness, aesthetic-emotional, and flexible. The latter four are regarded as impacting individuals while the first four impact organizations. The individual factors can be related to personal Internet use. Efficiency and effectiveness would positively influence the decision to use the Internet, if individuals thought using the Internet would make their lives easier, e.g. that they could get information faster, pay less money, etc. Aesthetic-emotional added values relate to subjective wellbeing or satisfaction with life, and flexibility added value relates to being able to perform daily tasks flexibly, e.g. on laptops, tablets, and smartphones without being bound to one specific location.

For many interviewees in Britain and Sweden using the Internet did not offer enough added values in any of the abovementioned realms to go through the effort of learning a new technology. They found their information easily enough elsewhere and did not feel that Internet use would improve their lives significantly.

This phenomenon is closely related to the availability of proxy-use through social networks. Even if they were aware of the benefits that Internet use might bring them, many of those non-users who were not planning to use the Internet themselves in the near future had family and friends who made regular use for them. For these non-users it was easier and more efficient if they did not use the Internet themselves. This was the case for a large number of non-users in both countries and was brought to the point by Gail:

Interviewer: Do you have any idea why, why you didn't feel like trying it before?

Gail: Well, it's laziness really, because my husband is very efficient on the computer and using the Internet and so l'm afraid l've left it to him.

\section{Future Use}

A notion strongly related to reasons for non-use and feelings about being offline is the likelihood of future use. We found that those interviewees who were happy with their situation as a non-user and especially those with a strong social network that used the Internet for them were the least likely to mention having an interest in going online in the future. These non-users also displayed lack of interest as one of their main reasons for being offline. This was often paired with a lack of 
skills, which means that non-users would have to put in time and effort to learn how to use computers and the Internet. The notion of being happy with their non-use was more prominent in Sweden than in Britain. This might be because the Swedish interviewees also reported having a stronger support network around them and coming from more advantaged socio-economic backgrounds.

In contrast to this, non-users who saw themselves as being outsiders or felt that they were missing out or being too dependent on their family and friends were more likely to consider going online in the future. However, many of them were held back by economic or time constraints, or felt that more basic things were of higher importance. A number of interviewees especially in Sweden mentioned that they had trouble with literacy and language, both of which are key factors for using the highly text-based Internet:

Interviewer: What is it you find difficult? Is it writing? Or reading?

Lina: Yes, writing, or finding the numbers and so. On keyboard is hard to do. Interviewer: Would you like to learn more?

Lina: Maybe. Maybe I need to but first I need to know how to read good Swedish, then I can use it but cannot read good Swedish - cannot use it, it is difficult. Although the number of respondents with these issues was smaller in Britain, more basic factors such as cost and basic skills were still important there as well.

The number of respondents who were highly likely to start using the Internet was higher in Britain than in Sweden. Often these non-users were facing a radical change in their living circumstances, which led to a change in behaviour. Ajzen (1991, p. 815) described this phenomenon in his 'Theory of Planned Behavior'. If a certain set of factors, and this includes proxy-use through social networks, “[...] remains unchanged, the behavior also remains stable over time" (ib., p. 202). Some of the interviewees found themselves in changed circumstances when partners died, they separated from a long-term partner, or their circumstances had changed due to other factors, such as health. While these major changes motivated some non-users to start learning how to use the Internet (e.g. Tom, Georgina, Gail) it led Barbara to stop using the Internet. This is again closely related to social networks. If the current proxy-users did not have others using the Internet for them, some of them would 
(have to) overcome their reservations and start using the Internet, as some of them also admit:

Johan: If you are self-employed in Sweden you need to have regular contact with the tax office [online]. And if I hadn't had an accountant I would have been much more interested and dealt with these things myself. Then l'd be forced to do that.

\section{Conclusion}

This paper set out to answer two important questions relating to reasons for non-use and perceptions and feelings of non-users in two technologized societies. The comparison of Great Britain and Sweden shows that we encounter similarities and differences in middle-aged non-user populations of both countries. Socio-economic factors, such as cost or employment, play an important role for non-users in both countries, as do basic factors, such as literacy. The data show that complex reasons, such as lack of interest or discomfort with technologies, should be considered in future research and policies regarding digital inequalities. The influence of social contacts that do use the Internet has previously been evaluated as exclusively positive. It was assumed that these social networks would encourage non-users to go online and that the availability of warm experts would provide the needed support to overcome technical difficulties and develop the necessary skills. While this is a valid point, our data show that social networks can also have the opposite effect and prevent non-users from learning how to use the Internet, as it is more convenient to stay a proxy-user instead.

\section{Policies}

The connotation of social desirability of Internet use in media, policies, and the surroundings of non-users makes many of them feel left behind (Klecun 2008) or even worse: stupid. A considerable number of non-users, however, were happy and successful without ever having used a computer or the Internet themselves. Similar to Selwyn (2006) we find that "[...] the perceived 'need' for all citizens to engage with ICTs in order to survive and thrive in the current information age - could therefore be considered erroneous in light of the many people in our study who were surviving (and often thriving) without it" (ib.: pp. 289). 
In light of many interviewees feeling left out, we come to the conclusion that it would be better to avoid stigmatizing non-use as something abnormal. Instead it would be valuable to highlight potential personal benefits for non-users. If non-users thought they could find things online that interest them, e.g. in relation to their hobbies, Internet use might become more attractive and motivate them to try it. Moreover, similar to illiteracy it is detrimental for Internet non-use to be a taboo topic. It would be more beneficial if policies promoted an open dialogue and hence enabled those who are struggling with literacy, computers, and the Internet to find the help they need.

\section{Future Research}

More research is necessary in the area of social networks and their potentially negative impact on Internet use that we found in our data. The notion that Internet users in close networks would automatically have a positive, encouraging influence on future use needs to be reconsidered and studied more closely. While the potentially positive influence of warm experts is undeniable, we need to look more into the potentially negative influence of these experts.

While the rich qualitative data showed a new facet of Internet non-use that has rarely been considered before, it only scratches the surface. More research is needed to find out about especially vulnerable groups, such as immigrants and those who are struggling with more basic problems, such as literacy. For many interviewees more substantial problems than Internet non-use came first on the agenda of things to be resolved. This suggests that socio-economic factors still play a big role in who is online and who is not.

\section{References}

Ajzen, I. (1991): The theory of planned behavior. In: Organizational Behavior and Human Decision Process, 50, 179-211.

Bakardjeva, M. (2005): Internet Society: The internet in everyday life. London, Sage. 
Creswell, J.W. (2009): Research Design: Qualitative, quantitative, and mixed methods approaches. Thousand Oaks/London: Sage.

Eynon, R., Helsper, E. (2011): Adults learning online: Digital choice and/or digital exclusion? In: New Media and Society, 13(4), 534-551.

Findahl, O. (2009): Who are excluded and why? A study of the non-users of the Internet. In: Cunningham, P., Cunningham, M. (Eds.): eChallenges e-2009 Conference Proceedings. IIMC International Information Management Corporation.

Flick, U. (2009): An introduction to qualitative research. Thousand Oaks/London: Sage.

Gaskell, G. (2000): Individual and group interviewing. In: Bauer, M.W., Gaskell, G.: Qualitative researching with text, image, and sound. A practical handbook, 38-56. Thousand Oaks/London: Sage.

Glaser, B.G., Strauss, A.L. (1967): The discovery of grounded theory: strategies for qualitative research. Chicago: Aldine Publishing.

Hargittai, E., Hinnant, A. (2008): Digital inequality: Differences in young adults' use of the Internet. In: Communication Research, 35(5), 602-621.

Helsper, E.J. (2011): The emergence of a digital underclass. Digital policies in the UK and evidence for inclusion. In: LSE Media Policy Project: Media policy brief 3. London: London School of Economics.

Holstein, J.A., Gubrium, J.F. (1995): The active interview. Thousand Oaks/London: Sage.

Kiel, J.M. (2005): The digital divide: Internet and e-mail use by the elderly. In: Informatics for Health and Social Care 30(1), 19-23. London/New York: Routledge. Klecun, E. (2008): Bringing lost sheep into the fold: questioning the discourse of the digital divide. In: Information Technology \& People 21(3), 267-282.

Kuhlen, R. (1996): Informationsmarkt: Chancen und Risiken der Kommerzialisierung von Wissen. Konstanz. 
Kvale, S., Brinkmann, S. (2009): InterViews: Learning the craft of qualitative research interviewing, 2nd Edition. Thousand Oaks/London: Sage.

Livingstone, S., Helsper, E. (2007): Gradations in digital inclusion: Children, young people, and the digital divide. In: New Media \& Society 9(4), 671-696.

Marshall, S.L., While, A.E. (1994): Interviewing respondents who have English as a second language: challenges encountered and suggestions for other researchers. In: Journal of Advanced Nursing 19(3), 566-571.

Miles, M.B., Huberman, A.M. (1994): Qualitative data analysis: An expanded sourcebook, 2nd Edition. Thousand Oaks/London: Sage.

Milligan, C., Passey, D. (2011): Ageing and the use of the Internet-Current engagement and future needs. A state of the art review. Oxford: Nominet Trust.

Office for National Statistics (2010): Statistical Bulletin: Internet access 2010. Households and individuals. Newport: Office for National Statistics.

Patton, M.Q. (2002): Qualitative research and evaluation methods, 3rd Edition. Thousand Oaks/London: Sage.

Race Online 2012: Available at: http://raceonline2012.org/ (Accessed: 24/01/2012)

Reisdorf, B. (forthcoming): Internet non-use: A comparative study of Great Britain and Sweden. Doctoral Dissertation. University of Oxford.

Reisdorf, B. (2011): Non-adoption of the Internet in Great Britain and Sweden: A cross-national comparison. In: Information, Communication \& Society 14(3), 400420.

Rogers, E. (1995): Diffusion of innovations. NewYork: Free Press.

Selwyn, N., Gorard, S., and Furlong (2005) Whose Internet is it anyway? Exploring adults (non) use of the internet in everyday life. European Journal of Communication, 20, 5-26.

Selwyn, N. (2006): Digital division or digital decision? A study of non-users and lowusers of computers. In: Poetics 34, 273-292. 
Selwyn, N. (2004): Reconsidering political and popular understandings of the digital divide. In: New Media \& Society, 6(3), 341-362.

Selwyn, N. (2003): Apart from technology: understanding people's non-use of information and communication technologies in everyday life. In: Technology in Society, 25, 99-116.

Silverman, D. (2000): Analyzing talk and text. In: Denzin, N.K., Lincoln, Y.S. (Eds.): The handbook of qualitative research, 2nd Edition, 821-834. Thousand Oaks/London: Sage.

Strauss, A., Corbin, J. (1998): Basics of qualitative research: Techniques and procedures for developing grounded theory, 2nd Edition. Thousand Oaks/London: Sage.

White, P., Selwyn, N. (2011): Moving on-line? An analysis of patterns of adult Internet use in the UK, 2002-2010. In: Information, Communication \& Society. Doi: 10.1080/1369118X.2011.611816.

Wyatt, S. (2003): Non-Users also matter: The construction of users and non-users of the Internet. In: Oudshoorn, N., Pinch, T. (Eds.): How users matter: The coconstruction of users and technologies, 67-79. Cambridge/MA: The MIT Press.

Zillien, U., Hargittai, E. (2009): Digital distinction: Status-specific types of Internet usage. In: Social Science Quarterly 90(2), 274-291. 